\title{
食中毒の原因となる水産物の寄生虫
}

\section{Parasites in Fisheries Food causing Food Poisoning}

\author{
横山 博
}

(岡山理科大学獣医学部)

Hiroshi YOKOYAMA

\section{1. はじめに}

近年，生鮮魚介類を喫食して食中毒に罹ったというマ スコミ報道が相次ぎ，一般の鮮魚店やスーパーにおいて 消費が急激に落ち込むという現象があった。その最たる ものは，アニサキス症であろう ${ }^{1,13,15)}$.2017年頃, 多数 の芸能人が寿司や生魚を食べてアニサキス症に罹ったと いう体験談が紹介され，さらに2018年にはカツオが原 因食品別の件数で急増したという報道により世間の関心 が高まった．同時に，アニサキスが食中毒の原因物質別 で第1位にもなったことは，一部の医療関係者を驚かせ たようである。しかし，海産魚におけるアニサキス寄生 は自然界で普通のことであり，現在，「アニサキス症」 として把握されているのは氷山の一角に過ぎないとも言 われている ${ }^{14)}$. また，この件数 1 位という点は，近年の 法改正によりアニサキスも食中毒病因物質として報告義 務が生じるようになったこととも大いに関係している.

もう一つの魚介類由来寄生虫症は, ヒラメのクドア食 中毒である ${ }^{5,12,19,20)}$. 2000年代初頭から病因物質不明の 有症事例として件数が増加し，いわゆる「謎の食中毒」 として知られていたが, 各方面の研究機関の成果によ り，2011年 4 月に開催された薬事・食品衛生審議会食品 衛生分科会食中毒・乳肉水産食品合同部会において, 「原因体は粘液胞子虫の1種, Kudoa septempunctataで ある」と結論付けられた. その後, 対策研究が進み発生 件数も落ち着き始め, 内閣府の食品安全委員会より総括 的な評価書が提出され，障害調整生存年（disability-adjusted life years: DALYs) は極めて小さいことも報告 されたので11), やや新鮮味に欠ける話題かもしれない. しかし，基礎研究的にも水産現場的にも，まだまだ多く の課題が残されている，そこで本論では，上記 2 種の水 産食品由来寄生虫症について, 最新の話題と今後の課題 について整理してみたい.

\section{* 連絡先}

Faculty of Veterinary Science, Okayama University of Science, 1-3 Ikoi-no-oka, Imabari, Ehime 751-5888

\section{2. 病因物質別食中毒の発生動向}

まず厚生労働省の食中毒統計資料を基に, Kudoa septempunctata（以下，クドア）が正式に食中毒病因物質 として認められた 2013 年より 2020 年まで 8 年間の事件 数と患者数の推移について,「クドア」と「アニサキス」 を他の重要な食中毒病因微生物である「カンピロバク ター・ジェジュニ/コリ」(以下，カンピロバクター）お よび「ノロウイルス」とともに見ていきたい.

表1で見られるように，カンピロバクターの事件数は 300 件前後でほぼ一定, ノロウイルスは変動が激しいも のの平均では同様に 300 件程度であった。 それに対し, アニサキスが 2017 年以降, 急増しているのが目立つ. 逆にクドアは 2014 年の 43 件をピークに最近 6 年間は 20 件弱と低值安定傾向にある.なお, 2020 年にカンピロ バクター, ノロウイルス, クドアの件数が例年より半減 したのは，いわゆる「コロナ禍」により大人数の宴会が 自肃されたことと関係しているかもしれない.

次に患者数を見てみると, カンピロバクターは平均で およそ2,000名であるのに対し，ノロウイルスは2013〜 2016年まで1万人を超えていたものが，2017年以降は減 少傾向にある. それらに対し，アニサキスは事件数と同 様, 2017 年以降の増加が顕著である. クドアは相対的 に絶対数こそ少ないものの, ここ数年は 200 名弱, 罹患 している．また，ここでもアニサキス以外の 3 種は 2020 年に例年の半数程度まで減少しており, コロナ禍の影響 が見て取れる.

ここで独自に，患者数を事件数で割った值を算出して みると，面白い傾向がみられた。この值は「1事件あた りの患者数」いわば集団食中毒リスクを現すデータとい えるが, 事件数のみ, 患者数のみで見たときと比べて, 年変動や社会情勢の影響をあまり受けない, 各食中毒特 有の数值が表現されているように思われる（図 1 )。つ まり，アニサキスは平均1.02（1.0～1.05)名/件と非常に 安定しているように見えるが，これは魚 1 尾に寄生して いるアニサキスをたまたま1名の患者が摂り込んでし 
表1. 主要な食中毒病因物質別の年間事件数と患者数の年次推移（厚生労働省・食中毒統計）

\begin{tabular}{llrrrrrrrr}
\hline & & 2013 & 2014 & 2015 & 2016 & 2017 & 2018 & 2019 & 2020 \\
\hline ノロウイルス & 年 & 事件数 & 328 & 293 & 481 & 354 & 214 & 256 & 212 \\
& 患者数 & 12,672 & 10,506 & 14,876 & 11,397 & 8,496 & 8,475 & 6,889 & 3,660 \\
\hline カンピロバクター・ジェジュニノコリ & 事件数 & 227 & 306 & 318 & 339 & 320 & 319 & 286 & 182 \\
& 患者数 & 1551 & 1893 & 2089 & 3272 & 2315 & 1995 & 1937 & 901 \\
\hline クドア & 事件数 & 21 & 43 & 17 & 22 & 12 & 14 & 17 & 9 \\
& 患者数 & 244 & 429 & 169 & 259 & 126 & 155 & 188 & 88 \\
\hline アニサキス & 事件数 & 88 & 79 & 127 & 124 & 230 & 468 & 328 & 386 \\
& 患者数 & 89 & 79 & 133 & 126 & 242 & 478 & 336 & 396 \\
\hline
\end{tabular}

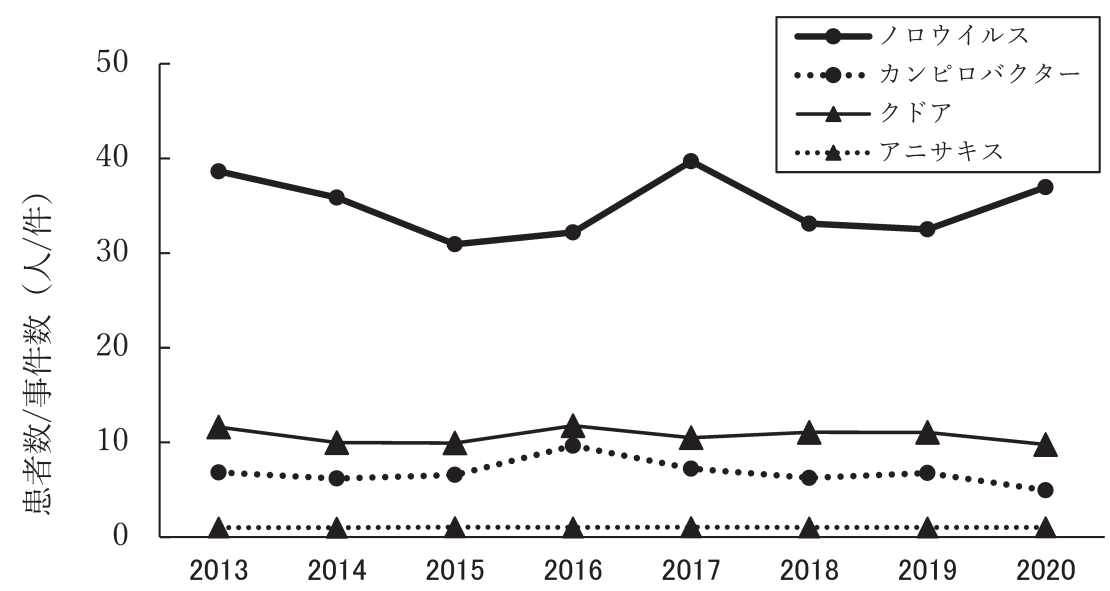

図1. 2013年〜 2020年における主要な食中毒病因物質別の「集団食中毒リスク」(=患者数／事件数（人／件)）の推移. ノロウイルス,

まったという状況を意味する，それに対してクドアは平 均 10.7 名/件と, カンピロバクターの 6.8 名/件を上回る リスクがあることを示す。これは，いくらクドアの事件 数が減少したとはいえ, 依然として警戒すべき食中毒で あることを示唆するデータといえるであろう。

\section{3. アニサキス症}

アニサキス症とは，アニサキス亜科線虫（多くはAnisakis simplex sensu stricto [狭義のA. simplex]まれに Anisakis pegreffii）の第3期幼虫が人体の胃壁または腸 壁に穿入して激しい腹痛，おう吐を引き起こす寄生虫症 である，人への感染源となるのは生鮮魚介類であり, 刺 身や寿司など海産魚の生食を嗜好する日本人に発生しや すい，そのため，古くからあった病気と考えられるが, 診断技術の高度化やコールドチェーンの発展に伴い，ア ニサキス症発生の増加や広域化が促されてきた。

とくに近年のアニサキス騒動を受ける形で, 岡山理科 大学・獣医学部・国際獣医教育研究センターの主催に㧤 いて，2021年 2 月に「アニサキス症 現状の課題と今後 の展望」というタイトルの第 3 回国際シンポジウムが ウェブ形式で開催された。本シンポジウムでは, (1)水産 学的立場から目黒寄生虫館の小川和夫博士, (2)寄生虫学 的立場からローマ・ラ・サピエンッァ大学の Simonetta
Mattiucci博士, (3)食品科学的立場から東京海洋大学の 嶋倉邦嘉博士，4医学抢よび行政対応の立場から国立感 染症研究所の杉山 広博士，という第一線かつ異分野の 研究者が一堂に会するというユニークな形式で行われ た. とくに講演会後に開催された討論会では, 視聴者か ら事前に寄せられた質問に演者が逐一応答する形で進行 する中，新たな課題も浮き彫りにされた．本討論会の記 録は上記センターのHP (https://iverc.vet.ous.ac.jp/sym posium/symposium2020/)上でも閲覧できるものの, 本 稿では議事内容を要約する形で整理する。

1）水産学的立場から〜カツオの事例が増えた理由

従来，アニサキス症の原因食品といえば，サバ類やイ カ類が筆頭に挙げられていたが，2018年に限っては， カツオが 100 件 (患者数 103 名) と圧倒的に多く, 前年 比 10 倍以上まで増加して水産関係者に衝撃を与えた。 また，この年はアニサキス症の件数がカンピロバクター やノロウイルスによる食中毒よりも上回り，食中毒の原 因物質として初めて1位になったことで世間を騒がせ た.

カツオは刺身としてだけでなく, 表面のみを采る「た たき」としても供されるため, 中心部が生のまま残され た魚肉中に活きたアニサキスが生残していたのであろ う. しかし, なぜ2018年になって突如, 急増したのか, 
同じ傾向は今後も継続するのか, 不明な点が多かったの で，厚労省を中心として研究グループが組織され，実態 調査が行われた。

その結果，カツオによる食中毒は「初ガツオ」の時期 である4〜 5 月に多く，「戻りガッオ」の秋季には少な かったこと, 寄生部位は筋肉より内蔵の方が多かったこ と, 漁獲から流通の間でアニサキスが内藏から筋肉に移 行した形跡がないこと, さらに2018年は黒潮の大蛇行 があったためカツオは例年より沿岸寄りに回遊したこ と，などが明らかになった．以上より，2018年は，たま たまカツオの回遊ルートが異なっておりアニサキスの中 間宿主となるオキアミ類を例年より多く摂餌した結果, アニサキスの寄生が重篤だったと推察された。今後はカ ツオの回遊ルートやアニサキスの寄生状況を定期的にモ ニタリングするとともに, 飲食店や魚販売店へ積極的に 情報提供することが提案された。

2) 寄生虫学的立場から（分類, 生態, 生物学)

アニサキス亜科線虫は, 終宿主としての海産哺乳類の 体内で生殖して卵が海中に放出されて孵化し，2回脱皮 して中間宿主としてのオキアミ類に取り込まれ第 3 期幼 虫まで発育する。その後, 食物連鎖に乗って魚類やイカ 類を延長中間宿主として成長し，終宿主に捕食されると 消化管に侵入して成虫となる。ヒトはアニサキスにとっ て本来の宿主ではない（偶然宿主）ため，成虫にはなれ ず，激しい腹痛や吐き気などを伴うアニサキス症を呈す る。アニサキスにはアニサキス症の原因となるAnisakis simplex s.s. 以外にも, A. pegreffiiやA. berlandiなど多 数の隠蔽種が存在するとされており，それらは幼虫の形 態学的特徴だけでなく，複数の遺伝子座を用いた分子 マーカーにより鑑別診断できる。それらは地理的分布や 宿主嗜好性などにおいて差異があり，同じ海域の中でも 棲み分けていることが報告されている．海洋生態系が健 全であることは，遺伝的変動性も高度に維持されてお り，アニサキス線虫における豊富な多様性を保証する。

\section{3）食品科学的立場から（アニサキス・アレルギー）}

アニサキスによるアレルギーは，いわゆるアニサキス 症とは異なり，アニサキス由来の成分を抗原として $\operatorname{IgE}$ 抗体が関与するI型 (即時型) アレルギーのことであ る. 実際の症例において, サバを食べて尋麻疹を発症し た患者のうち，多くの患者がサバに対してではなくアニ サキスに対して反応していたことも明らかになってい る.このアレルギーのメカニズムには不明な点が多いも のの，食物アレルギーと同様，最初は生きたアニサキス を取り込んだことによる感作が必要であるとされ，消化 管粘膜に侵入する際の分泌物の放出が感作の原因になる と推測されている。 アニサキスの主要抗原のうち，分 泌・排泄抗原であるAni s 1 は強い耐熱性を有している ことから，アニサキス症の対策として一般に知られる 「加熱処理」は有効でない。またアニサキスのアレルゲ ンにも非常に多くの種類が発見されただけでなく，スキ
ンプリック・テストで判明する患者ごとのパターンも異 なっているので, 治療においては患者ごと, オーダー メードの対応が必要となる。とくにアニサキス特異 IgE を保有している場合は即時型アレルギーを発症する危険 性が高いので, 要注意である.

4）医学および行政対応の立場から（診断, 治療, 予防）

日本では寿司，刺身など海産魚の生食が一般的である ことから，日本国内でのアニサキス食中毒は必然であ り，実際に発生数は極めて多い。魚介類の生食で数時間 以内に激しい腹痛が起きた場合は，まずアニサキス食中 毒を想定して受診し，生検鉗子で胃粘膜に穿入した虫体 を摘出することで容易に治療できる，たた，同じアニサ キス症といっても，胃アニサキス症以外に腸アニサキス 症やアナフィラキシー反応があることも忘れてはならな い. 厚生労働省の食中毒統計では年間 500 件弱が報告さ れているものの, 診療報酬明細書に基づくレセプト解析 の結果，実際にはその15倍もの事例があると推測され $る^{14)}$. 行政的には, 2012年12月の食品衛生法施行規則 の一部改正があり，アニサキスが新たに独立した食中毒 病因物質として追加された。つまり，最近のアニサキス 食中毒の急増は, この法改正によって医師が積極的に報 告するようになったことと無縁ではない。アニサキス食 中毒の予防法として, 1 . 加熱 $\left(60^{\circ} \mathrm{C} \cdot 1\right.$ 分間以上), 2. 冷凍 $\left(-20^{\circ} \mathrm{C} \cdot 24\right.$ 時間以上), 3. 魚の内臓を生で食べ ない・提供しない，4. 新鮮な魚を購入して速やかに内臓 を除去する，5. 養殖魚（閉鎖式陸上養殖）を喫食する， 6. 塩, わさび, 醤油, 酢のような調味料は効果がない, などがある。今後はアニサキス症の存在を周知するのみ ならず，上記の対策を啓発普及することが重要である.

5) まとめ

・近年のカツオの流通はコールドチェーンが完備されて いるので, 冷蔵状態の魚の内臓から筋肉に虫が移動す ることはほとんどないと思われる，そのため，筋肉中 に存在していたアニサキスは，生時から寄生していた と考えてよい。今後の対策として，寄生の程度が比較 的，低い背側の肉を刺身や「たたき」として提供し， 腹身はなるべく熱を通して供することが推奨される. ・カツオのアニサキス食中毒が問題になったのは, いわ ゆる「初ガツオ」の時期だけであり，「戻りガッオ」 の時期には必ずしも増加していない，その間の状況は 不明であるものの，福島県と高知県の行政対応や，魚 市場等の業者内での現場対応が奏功した結果ではない かと推測される.

・従来, 確立されてきた対策（加熱・冷凍処理, 養殖魚 の契食など）の普及のみならず，リスクの高い魚種を モニタリングして積極的に情報公開する。

\section{4. クドア食中毒}

クドア食中毒とは, Kudoa septempunctata という粘 液胞子虫に寄生したヒラメを生食後, 数時間程度で一過 
性のおう吐や下痢を呈する寄生虫症である ${ }^{11)}$ 。発生当 初は, ヒラメ肉の加熱 $\left(75^{\circ} \mathrm{C} \cdot 5\right.$ 分間以上) または冷凍 $\left(-15^{\circ} \mathrm{C} \sim-20^{\circ} \mathrm{C} \cdot 4\right.$ 時間以上) 処理が推奨されたが, 生食嗜好の食習慣には馴染まないものであった ${ }^{11)}$ 。そ の後, 養殖ヒラメにおいては種苗生産過程で飼育用水の 紫外線処理 ${ }^{8)}$, 養殖場への導入時と出荷時にそれぞれ PCR 検査と顕微鏡検査を徹底すること ${ }^{2)}$ 。また輸入ヒラ メにおいては通関時に定量 PCR 検査を実施することな どの対策が開発された ${ }^{3)}$. その後の 2015 年, 内閣府の 食品安全委員会より評価書 ${ }^{11)}$ が提出されたことで，本 問題は一件落着してしまったかのように見える。たしか に食品衛生上は一定の対策が見出され, 食中毒の報告件 数も落ち着いているが，本当にそう断言していいのだろ うか. 莫大なコストの掛かる研究を今後も継続する価值 があるかどうかを見極めるためにも，残された課題を記 述しておくことは意義深いと考え, 本稿で改めて整理し たい.

\section{1）食中毒件数は減少しているか?}

ここ 3 年間は事件数が十数件以下（とくに 2020 年は 9 件)，患者数も100名台（2020年は二桁）に抑えられて おり，減少傾向は明白である（表1）。その理由は明ら かでないが，国内における生産・流通業者の対応，およ び検疫所での対策が総合的に効いていると考えられる.

\section{2)「評価書」11) に記載された予防・対策は機能してい} るのか?

養殖ヒラメの生産・出荷 · 流通時, 天然ヒラメの出 荷・流通時，および輸入ヒラメの通関時，各段階におけ る検査がどの程度，機能しているのかは明確でない，国 内産ヒラメに限っていえば，養殖ヒラメの生産から出荷 までの過程で無感染ヒラメを作製・維持することは，自 らの利益を守る意味で正当性がある. 一方, 天然ヒラメ については捕獲した漁師や出荷する魚市場が自主的に検 査する合理性がない（費用対効果が悪い)。この点に関し ては，責任の所在を明らかにする法整備をする必要があ るかもしれない.さらに, 韓国産ヒラメに対して検疫所 でどの程度（頻度や割合など）調べているのか不明であ るし，そもそも韓国からの輸出時に検査する必然性がな いので，実態は把握できていないと言わざるを得ない.

3）発症メカニズムは解明されたか?

スンクスや乳のみマウスを用いた動物実験系と, Caco-2などの腸管上皮株化細胞を用いた実験系を組み 合わせて, 微細構造・化学物質・分子レベルにおけるメ カニズムの一端が解明されつつある。下痢原性は乳のみ マウスを用いて証明され，その定量的指標となる FA 值 （腸管内の液体貯留值）の有意な増加をもたらす胞子の 投与量は， $1.3 \times 10^{6}$ 胞子/匹であった ${ }^{5)}$ 。おう吐毒性はス ンクスを用いて証明され，おう吐に必要な用量は，4-6 $\times 10^{7}$ 胞子/匹であった ${ }^{5)}$. おう吐の発症には，腸クロム 親和性細胞 (EC細胞) 様ヒト膵島細胞がん細胞株 QGP-1細胞を用いた実験により，七ロトニンが関与する
メカニズムが示唆されている ${ }^{9)}$ 。 また，DNAマイクロ アレイ法を用いて，インターロイキン (IL-8) やセロト ニン（5-HT）がおう吐に関与する可能性も示されてい る ${ }^{18)}$ 。なお，食中毒を引き起こす最少胞子摂取量につ いては, 疫学調查によって一人当たり $7.2 \times 10^{7}$ 個と見積 もられている17)。以上のように，病原体と食中毒の因 果関係は証明されたといえるものの，メカニズムの全容 が解明されたとまではいえない.

4）ヒラメ以外の感染魚種はあるか? また害があるの はK. septempunctataだけか?

クドア属粘液胞子虫で単一の魚種のみを宿主とする種 類は多くないので, 他の魚種にも罹っている可能性は十 分に考えられる20)。すでに， ウマヅラハギとクサフグ およびシロギスからも検出されており，フグ科魚類が 「本来の宿主」であることが示唆されている ${ }^{4,10)}$. しか し, いずれも軽度の感染であり食中毒事例としては報告 されていないので，水産的に警戒するレベルではないも のの，今後，注視しておくべきであろう。

その他, 各種海産魚の筋肉に寄生するKudoa iwatai, クロマグロ幼魚（メジマグロ）に寄生するKudoa hexapunctata, カンパチに寄生するUnicapsula seriolaeによ る有症事例が知られている6,7,16). 今後, 因果関係の特 定はもちろん, 水産的には食中毒を導く最少胞子摂取量 の閾値を決定することが肝要である.

\section{5）残された課題}

魚類寄生虫症の場合，良からぬ問題が起こるとマスコ ミ等により一時的に大騒ぎするが，収束した時に「なぜ 収まったか？」が検証されるケースはほとんどない。そ れは, 過去, 水産食品の市場価格がいわゆる風評被害に より過剩に振り回されてきた経緯があるからである。現 在，ヒラメのクドア食中毒が収まっているのは，関連業 者の徹底的な検査の故であることは間違いないが，当 然，そこには手間とコストが掛かっている。「食の安 全・安心」を保証するための検査の実施を社会で情報共 有し，正当に評価することが望まれる.

今後, クドア食中毒の発病メカニズムを解明するこ と，また他の粘液胞子虫種による食中毒の特性を明らか にすることが必要である. しかし，さらなる研究の進展 には, in vitro培養や冷凍保存のできない生鮮クドアを 常時入手できなければならない。そのためには，活きた ヒラメに感染させて生活環を実験施設内で絶えず維持し ておくという, 高リスクかつ労力も要る作業が必要とさ れ, 病原体の撲滅と逆行する点において, 現実的ではな いかもしれない.

\section{謝 辞}

本稿に関して貴重なご意見をいただいた関係各位に感 謝いたします。 


\section{文献}

1) Abe, N.: Application of the PCR-sequence-specific primers for the discrimination among larval Anisakis simplex complex. Parasitol. Res., 102, 1073-1075 (2008).

2) Grabner, D. S., Yokoyama, H., Shirakashi, S. and Kinami, R.: Diagnostic PCR assays to detect and differentiate Kudoa septempunctata, K. thyrsites and K. lateolabracis (Myxozoa, Multivalvulida) in muscle tissue of olive flounder (Paralichthys olivaceus). Aquaculture, 29, 338-341 (2012).

3) Harada, T., Kawai, T., Sato, H., Yokoyama, H. and Kumeda, Y.: Development of a quantitative polymerase chain reaction assay for detection of Kudoa septempunctata in olive flounder (Paralichthys olivaceus). Int. J. Food Microbiol., 156, 161-167 (2012).

4) Kasai, A., Li, Y.-C., Mafie, E. and Sato, H.: New host records of monacanthid fish for three Kudoa spp. (K. septempunctata, $K$. thyrsites and $K$. shiomitsui) prevalent in the olive flounder (Paralichthys olivaceus), with the description of $K$. parathyrsites $n$. sp. from a black scraper (Thamnaconus modestus). Parasitol. Res., 115, 2741-2755 (2016).

5) Kawai, T., Sekizuka, T., Yahata, Y., Kuroda, M., Kumeda, Y., Iijima, Y., Kamata, Y., Sugita-Konishi, Y. and Ohnishi, T.: Identification of Kudoa septempunctata as the causative agent of novel food poisoning outbreaks in Japan by consumption of Paralichthys olivaceus in raw fish. Clin. Infect. Dis., 54, 1046-1052 (2012).

6）川瀬雅雄, 猪又明日香, 木村有紀, 白幡祐子, 紫竹美和 子, 岡田 涼, 安齋久恵: Kudoa hexapunctataが原因と 疑われる有症事例の発生一新潟県. 病原微生物検出情 報, 37, 238 (2016).

7）丸山暁人, 藤田愛里, 池上絵理子, 野島誠治, 難波利 元, 田渕文子：カンパチに寄生したKudoa属に近縁な粘 液胞子虫Unicapsula seriolaeの関与が疑われる集団有症 事例一広島県. 病原微生物検出情報, 39, 225-226 (2018).

8) Nishioka, T., Satoh, J., Mekata, T., Mori, K., Ohta, K., Morioka, T., Lu, M., Yokoyama, H. and Yoshinaga, T.: Efficacy of sand filtration and ultraviolet irradiation as seawater treatment to prevent Kudoa septempunctata
(Myxozoa: Multivalvulida) infection in olive flounder Paralichthys olivaceus. Fish Pathol., 51, 23-27 (2016).

9）大西貴弘：生鮮食品を共通食とする原因不明食中毒の発 症機構の解明. 平成 24 年度厚生労働科学研究費補助金 食品の安全確保推進研究事業 (2013).

10） Shirakashi, S., Shin S. P., Mekata T., Kiryu I.: Infections of Kudoa septempunctata (Myxozoa: Multivalvulida) in wild grass puffer Takifugu alboplumbeus and Japanese whiting Silago japonica. Fish Pathol., 56, 140-148 (2021).

11）食品安全委員会：寄生虫評価書 ヒラメの Kudoa septempunctata, 1-62 (2015).

12) Sugita-Konishi, Y., Sato, H. and Ohnishi, T.: Novel foodborne disease associated with consumption of raw fish, olive flounder (Paralichthys olivaceus). Food Safety, 2, 141-150 (2014).

13）杉山 広：食中毒としての食品媒介寄生虫症：現状と検 查の課題. 日食微誌, 33, 134-137 (2016).

14）杉山 広, 森嶋康之, 大前比吕之, 山崎 浩, 木村信 也：アニサキスによる食中毒：届出に関わる法改正とレ セプトデータに基づく患者数の推計. Clin. Parasitol., 24, 44-46 (2013).

15）鈴木 淳：アニサキスによる食中毒とその原因食品. 日 食微誌, 37, 122-125 (2020).

16）塚田竜介, 井川由樹子, 小野諭子, 和田純子, 北條博 夫, 小平 満, 大西貴弘：Kudoa iwataiが原因と疑われ た有症苦情事例について一長野県. 病原微生物検出情 報, 39, 224-225 (2018).

17) Yahata, Y., Sugita-Konishi, Y., Ohnishi, T., Toyokawa, T., Nakamura, N., Taniguchi, K. and Okabe, N.: Kudoa septempunctata-induced gastroenteritis in humans after flounder consumption in Japan: a case-controlled study. Jpn. J. Infect. Dis., 68, 119-123 (2015).

18) Yamamoto, S., Kawano, F., Yokoyama, H. and Kobayashi, S.: Effects of Kudoa septempunctata infections in a human intestinal epithelial model (Caco-2): a DNA microarray study. Biosci. Biotech. Biochem., 84, 1030-1038 (2020).

19）横山 博：魚介類の生食による寄生虫症. 日食微誌, 30, 100-103 (2013).

20）横山 博：クドア症. 魚病研究, 51, 163-168 (2016). 